\title{
ЯЗЫКОВАЯ ЛИЧНОСТЬ ПЕРСОНАЖА ДРАМАТУРГИЧЕСКОГО ПРОИЗВЕДЕНИЯ В ПЕРЕВОДЕ И ПОСТАНОВКЕ (ПО МАТЕРИАЛАМ ПЬЕСЫ Н. В. ГОГОЛЯ ЖЕНИТЬБА)
}

\section{Language Personality of Drama Characters in Translation and Stage Realization (Based on N. Gogol's "Marriage")}

Keywords: drama translation, stage translation, language personality in translation Contact: Uniwersytet Śląskiw Katowicach; maciekmalek93@gmail.com

Антропоцентрические исследования в современной науке становятся все более актуальными, востребованными и перспективными. Эти явления нашли отражение также в лингвистических исследованиях, в том числе и в переводоведении.

В настоящей статье мы попытаемся обсудить вопрос языковой личности ${ }^{1}$ в драматургическом произведении, а точнее - в его сценической реализации.

Выражение «языковая личность» было введено в употребление Виктором Виноградовым (Виноградов 1930), но опыт описания героев с точки зрения употребляемой ими речи, приобрел популярность благодаря работе Юрия Караулова - Русский язык и языковая личность (Караулов 1987). Языковую личность будем понимать как «совокупность психофизических свойств индивида, позволяющую ему создавать и воспринимать речевые произведения» (Никандрова 2010: 15). В художественном тексте это, прежде всего, духовный облик, отражающийся в языковой форме с помощью речевых ходов. Вслед за Ю.Н. Карауловым мы будем различать три группы проявления языковой личности (Хисамова 2014: 215): 1) вербально-семантическую (языковые единицы), 2) лингвокогнитивную (иерархия ценностей), 3) прагматическую. Все эти три группы являются существенными в процессе анализа языковой личности, в связи с чем нельзя, как нам кажется, рассматривать их отдельно. Караулов

\footnotetext{
${ }^{1}$ Следует учесть, что этот термин не ограничивается только рамками лингвистики, но употребляется во многих дисциплинах, таких как психология, социология, философия, литературоведение и др.
} 
Языковая личность персонажа драматургического произведения в переводе и постановке (по материалам пьесы Н. В. Гоголя Женитьба)

подчеркивал, что именно такой комплексный подход дает представление о мировоззрении анализируемого персонажа. В. А. Маслова считает, что языковая личность содержит следующую информацию: социальный статус, уровень образования, тип характера, пол, возраст, национальная принадлежность и др. (Маслова 2001: 119).

Как было уже сказано, настоящая статья посвящена характеристике особенностей речевого поведения гоголевских героев в переводе и сценической постановке. Караулов отмечает, что одной из более продуктивных языковых личностей является именно литературный герой, которого издавна изучали представители литературоведения. Для того, чтобы хорошо прочувствовать персонаж - его характер, личность - следует тщательно проанализировать его поведение, которое хоть и находит свое отражение в речи, формируется благодаря ее богатству. Основой для анализа языковой личности является, прежде всего, лексическая сторона текста. Затем идет его прагматическая характеристика. В случае сценического текста, который на конечном этапе должен прозвучать со сцены - это также невербальные элементы, как громкость, тон, темп, ритм, высота звука и другие. Невербальные элементы могут появиться либо в начале произведения (Харита Игнатьевна Огудалова, вдова средних лет; одета изящно, но смело и не по летам. Лариса Дмитриевна, ее дочь, девица; одета богато, но скромно) (Островский 1950), либо во внешних ремарках (Ольга в синем форменном платье учительницы женской гимназии, все время поправляет ученические тетрадки, стоя и на ходу; Маша в черном платье, со иляпкой на коленях сидит и читает книжку, Ирина в белом платье стоит задумавшись) (Чехов 1986). Могут также присутствовать в высказываниях другого персонажа (Фекла: Акинф Степанович Пантелеев, чиновник, титулярный советник, немножко заикается только, зато уж такой скромный) (Гоголь 1994).

В таком случае переводчик выступает медиатором между двумя культурами. Он декодирует исходное сообщение, делая его понятным представителям другой культуры. В театре, эта работа видна уже во время театральных читок, настольных репетиций или репетиции на сцене. Создавая образ персонажа, автор, закрепляет в нем ряд характеристик, нужных для правильного восприятия его роли в данном сюжете. Из этого следует, что переводчик должен позаботиться о том, чтобы все эти черты сохранились в переводе. Среди них можно выделить следующие: портретные характеристики (лицо, фигура, одежда), жизненная ситуация героя, оказывающая влияние на его поведение, эмоции, интеллектуально-культурный уровень говорящего и др. 
Женитьба Н. В. Гоголя - это комедия быта и нравов. Сюжет пьесы построен вокруг события, которое в конечном итоге не состоялось, т. е. женитьбы Подколесина и купеческой дочери Агафии Тихоновны, которая желает выйти замуж за дворянина. Это произведение с одной стороны смешно, с другой же Гоголь указывает читателю целую галерею серых, нелепых и скучных героев, жизнь которых бессодержательна и бессмысленна. Кажется при этом, что они сами этого не замечают. Женитьба высмеивает не только черты характера и индивидуальные особенности героев, но и отдельные социальные явления. Герои, выведенные Гоголем, комичны - но вызывают не только улыбку и смех.

Материал для исследований является богатым и интересным, однако в настоящей статье мы займемся лишь двумя выбранными нами персонажами, представляющими собой весьма интересные личности. Первый из них - это Фекла Ивановна, сваха, которая сама представляет себя как довольно пожилую женщину, на что указывает слово бабушка в обращении к Кочкареву: Да ведь mbl ж сам пристал: жени, бабушка, да и полно... В польском переводе же эта характеристика не сохранилась: - Sam się czepiłés, ożeń mnie, kochanieńka, no to $m a s z . .{ }^{2}$ Однако, переводчик компенсировал эту потерю в другом месте. Фекла лживая и хитрая женщина. Врет женихам о невестах, а невестам приукрашает достоинства женихов. Кроме того, она ловко выкручивается из любой ситуации, когда ее уличают во лжи. Для характеристики Феклы важно то, что она имеет дело не с самыми богатыми женихами и невестами, т. е. не находится среди высших классов. На этот факт указывает ярко ее язык, в котором часто появляются неправильные формы слов:

...жила прежде с сенатским

оберсеклехтарем
...каменньй дом в Московской части,
о двух елтажсах.

Это уж такой великатный!

Да уж обноковенно, как не понимать. ...przedtem żyła z nadsekretarzem senatu.

...dom murowany na Moskiewskiej stronie, dwa piętra.

Ten to już taki delikatny!

No to przecież wiadoma rzecz, ja nie rozumieć.

\footnotetext{
${ }^{2}$ Бабушка - польск. - babcia, babciu; в русской культуре также адресатная форма, называющая любую пожилую женщину; kochanieńka - pусc. дорогуша.
} 
Первые три примера указывают на мнимый словарный запас Феклы. Она где-то эти слова слышала, но употреблять их правильно она не умеет. Фекла вставляет, например, в середину слова лишние звуки (явление эпентезы). В первом случае вместо обер-секретарь употребляет форму оберсеклехтар. Во втором - искажает слово этаж. Третий пример - это также искаженная форма слова: великій, дъьликатный, в значении - 'изысканный' (Даль 1880: 178). К сожалению, эти явления не нашли отражения в польском переводе. Таким образом, читатель утрачивает возможность оценить специфику речевого поведения героини. Последний пример связан с фонетическим обликом диалектного слова. Это не только употребление в речи диалектного слова (которого не употребил бы образованный человек), но также его фонетического варианта. Этот элемент также остался без перевода. Учитывая возможные прагматические потери, переводчик решил компенсировать эти элементы в других местах, например, в случае, где нейтральное выражение большое общество заменяется разговорным словом ludziska:

\section{Пивной погреб тоже большое} общество привлекает.
Tak samo piwiarnia dużo ludzisków przyciaga.

Следует, однако, учитывать тот факт, что в количественном плане значимых элементов намного больше в подлиннике. Некоторые из них в переводе сохранились. К ним принадлежат, в частности, всякого рода междометия и восклицания, а также ненормативная лексика. Переводчику удалось аккуратно подобрать аналоги этих элементов (как нам кажется, благодаря близости русской и польской культур) и тем самым передать эмоциональность и все прочие речевые характеристики Феклы. Проиллюстрируем это следующими примерами:

\begin{tabular}{l|l} 
Да, такой великатес! & Jak ta cukrownia! \\
\hline Да помилуй, отец! & Zmiłuj się, panie! \\
\hline Aх, бесстьцдик какой! & Ach, ty, wstydu nie masz! \\
\hline Мать моя! & Serdeńko!
\end{tabular}

Восклицания могут внушать, что у говорящего нет соответствующих аргументов, в связи с чем он вынужден для достижения своей цели использовать 
речевые средства, типичные для выражения агрессией и чрезмерной эмоциональности. Помимо прочего, восклицания свидетельствуют также о вовлеченности оратора в тему:

\begin{tabular}{l|l} 
Бесстыдник! & Ту bezwstydniku! \\
\hline $\begin{array}{l}\text { А я скажу, что ты сам подлец, вот } \\
\text { что! }\end{array}$ & A ja ci powiem, że sam jesteś gatgan, o!
\end{tabular}

Несмотря на то, что Фекла - простая женщина, она точно знает, что «даме» нельзя употреблять мат или ругательства. Имея это в виду, Фекла применяет эти языковые средства только в таких ситуациях, когда ее эмоциональная возбудимость достигает максимума.

Стоит еще уделить внимания употребляемым Феклой фразеологизированным конструкциям и просторечию. Они типичны для народной культуры. Их ролью является указать на происхождение свахи и ее социальный статус, т. е. являются очень важным элементом ее характеристики. Тем не менее данные явления не особо проявляются в польском переводе:

\section{Гляди налёт на свой полёт, а и} похвастаться нечем: шапка в рубль, а щии без круп.
Pilnuj swego, nic ci do tego; sam nie masz czym się pochwalić: ani łomu, ani domu, kieszeń na suchoty stęka.

Приведенные выше примеры можно охарактеризовать как лексические и морфологические. Немного иначе ситуация выглядит в случае синтаксических и прагматических структур. Хорошо отражает это пример, который приводим ниже. Обнаруживаем в нем повторения и вкрапления, а также просторечные синтаксические конструкции. Устная речь, как известно, характеризируется речевой недостаточностью, возникающей в случае, когда говорящий торопится и не следит за правильностью высказывания. Это небрежное отношение к языку может привести, например, к явлениям случайного пропуска слов, необходимых для точного выражения мысли. И хотя не всегда они проявляются в переводе в аналогичном месте как в подлиннике, то речевые характеристики на этом уровне, как правило, сохраняются.

Да уж обноковенно, как не понимать. No to przecież wiadoma rzecz, jak nie Был у нас и надворный советник, да $\quad$ rozumieć. Mieliśmy tam już radcę $d$ woru, 
Языковая личность персонажа драматургического произведения в переводе и постановке (по материалам пьесы Н. В. Гоголя Женитьба)

отказали: не понравился. Такой уж у него нрав-то странный был: что ни скажет слово, то и соврет, а такой на взгляд видный. Что ж делать, так уж ему Бог дал. Он-то и сам не рад, да уж не может, чтобы не прилгнуть. Такая уж на то воля Божия. ale odszedt z kwitkiem: nie spodobat się. A bo to dziwactwo taie miat: co stowo powie - to skłamie, choć na oko postawny. Co poradzisz, takim go Bóg stworzyl. Sam nawet nie chciat, tylko nie mógt inaczej, żeby nie zelgać. Wola boża.

Подытоживая наши размышления о речевой характеристике Феклы, можно сослаться на слова В. Г. Белинского, который констатирует: «Бойкость, яркость движений, трещоточный разговор должны быть прежде всего схвачены актрисою, выполняющею эту роль; малейшая вялость, тяжеловатость сейчас испортят дело. Это баба, наметавшаяся в своем ремесле; ее не расстроит никакое обстоятельство, не смутит никакое возражение; у нее готов ответ на всякий вопрос» (Белинский 1843: 46-51).

В рецензиях спектакля можно найти информацию относительно того, как все это было осуществлено в Силезском театре в городе Катовице?: «Пальму первенства держит феноменальная Эва Лесняк, которая энергично сыграла роль Феклы Ивановны» (Karkoszka 2015). «Эва Лесняк максимально подогревает интригу, и хотя ее унижают, она все-таки всеми управляет и ведет себя на сцене как восемнадцатилетняя девушка» (Kociński 2015). «Фекла, как лучший живописец итальянского ренессанса, вместо кисти использует слова, жесты и мимику» (Domagała 2015). «Эва Лесняк в роли Феклы Ивановны - громкая как торговка» (Lubina-Cipińska 2015).

Из этих рецензий можно узнать, что в принципе все черты, на которые обратил внимание Белинский, удалось сохранить и в польской постановке. Следует, однако, помнить также о том, что кроме переводимого текста, на создание образа Феклы повлияли еще ее поведение, проксемика и кинесика. Такие элементы сложно отразить с помощью слов в сценарии. В их реализации нужна креативность актрисы. Она является результатом тщательного анализа произведения, застольных репетиций, театральных читок, работы с режиссером, работы с переводчиком и многих других факторов индивидуального характера.

Второй интересующий нас здесь персонаж - Арина Пантелеймоновна значительно отличается от Феклы Ивановны. В лице этой героини (а также купца Старикова) Гоголь хотел показать, что положительные черты русского народа все 
еще живы. Тем самым писатель проявил свои националистические наклонности и желание идеализировать патриархальные «добрые времена».

Арина Пантелеймоновна является теткой Агафии Тихоновны. Это женщина с сильным характером, но одновременно нежная и любящая свою племянницу. Она уговаривает Агафью выйти замуж за купца, но не заставляет ее силой.

В переводе переводчику следует заметить разницу в речевом поведении родной Агафьи и сохранить типичный для нее регистр языка. Проиллюстрируем это примерами:

\begin{tabular}{l|l}
$\begin{array}{l}\text { A по какой причине изволили } \\
\text { одолжить посещением? }\end{array}$ & $\begin{array}{l}\text { A z jakiego powodu raczyli panowie } \\
\text { zaszczycić nas swoja obecnością? }\end{array}$ \\
\hline $\begin{array}{l}\text { Хоть подрядов никаких не берем, a } \\
\text { приходу рады. А как по фамилии? }\end{array}$ & $\begin{array}{l}\text { Jakkolwiek żadnych dostaw się nie } \\
\text { podejmiemy, to wizyta nas cieszy. }\end{array}$ \\
\hline $\begin{array}{l}\text { Прошу покорнейше садиться. (...) A } \\
\text { позвольте узнать... }\end{array}$ & $\begin{array}{l}\text { Proszę uprzejmie siąść. (...) Będzie pan } \\
\text { taskaw... }\end{array}$
\end{tabular}

Из данных примеров следует, что для героини характерен культурный, элегантный язык. Все это находит отражение в переводе. Помимо прочего, следует здесь обратить внимание на устаревшие языковые формы и их функции в речи. К ним принадлежит, например, наречие покорнейше или глагол одолжить, которые являются элементом стилизации речи Арины. Переводчик, правда, не всегда использует аналогичные приемы, тем не менее, что ему удается сохранить изысканную форму высказывания, например, с помощью употребления слов и выражений типа: raczyli, zaszczycić swoja obecnościa, będzie pan łaskaw...

Однако, такое речевое поведение не свидетельствует о том, что героиня не способна выражать сильные эмоции. В соответствующих моментах она использует восклицания, обращается к Богу, т. е. выражает и злость, и тревогу. В таких моментах в польском переводе применяются, например, уменьшительноласкательные слова и аугментативы, усиливающие использованное слово.

Врешь, врешь: дворянин..

Губернахтор больше сенахтора!

Разносилась с дворянином! а дворянин при случае так же гнет шапку.
Łżesz, tżesz: szlachcic... Gubernator jest nad senatorem! Rozpanoszyta się tu ze swoim szlachciura! A szlachcic, kiedy musi, tak samo w pas się klania... 
Языковая личность персонажа драматургического произведения в переводе и постановке (по материалам пьесы Н. В. Гоголя Женитьба)

\begin{tabular}{l|l} 
Ax, мать моя, беги скорей одеваться! & Ach, leć prędziutko, skarbie, ubieraj się! \\
\hline Ax, Господи милосердный, не погуби! & Bоże mitosierny, zmiłuj się nad nami!
\end{tabular}

Здесь опять в оригинале наблюдаем явление эпентезы. В обыденной речи эпентеза воспринимается как ошибка, но в художественном произведении трактуется как средство речевой характеристики героев. Она встречается, прежде всего, в ненормированной речи - просторечии, диалектах.

Арина Пантелеймоновна - это персонаж второго плана, но ее характер хорошо виден на фоне целого произведения. Это находит отражение также в переводе. Роль Арины в Силезском театре исполняла актриса Кристина Вишневска, о которой в рецензиях писали следующим образом: «Кристина Вишневска (Арина Пантелеймоновна, тетка) построила свой персонаж, как будто в противостоянии; она - тихая, тонкая, но не такая тупая. Потанцевать и попеть также сумеет» (Kociński 2015).

Здесь выявлены все основные черты героини. С одной стороны, она вписывается в пласт русского мещанства, а с другой же - остается среди нелепых и нищих родственников и знакомых.

Несмотря на то, что мы представили лишь самые яркие примеры языковой личности и возможностей ее перевода, нам кажется, что они отчетливо определяют проблему. Предпереводческий анализ произведения позволит понять переводчику, что Гоголь тщательно наблюдал за социумом, который представлял в своих произведениях. Это важно, так как в лицах всех действующих героев представлен весь спектр мыслей и чувств, а речь персонажей же является его уникальным отражением.

\section{Summary}

In the text the reader is told about translation and stage realization of language personality of drama character. The research material was a few characters from N. Gogol's drama "Marriage" and its stage realization in Silesian Theatre in Katowice. The author uses this examples to show how significant is understanding the purpose of implicit language information. The author emphasizes his thesis by quoting theatrical reviews in which theatrical performances of particular actors / characters are evaluated. In the conclusion the author sums up the main problems and challenges which can be met in process of translation. 


\section{Литература}

Виноградов, В. В. О художественной прозе. Москва: Наука, 1930.

Гоголь, Н. В. Женитьба. Москва: Русская книга, 1994.

Караулов, Ю. Н. Русский язык и языковая личность. Москва: Наука, 1987.

Маслова, В. А. Лингвокультурология. Москва: Академия, 2001.

Никандрова, И. А. Языковая личность персонажа: лингвистический аспект исследования. Вестник Вятского государственного университета. 2010 (2/2), с. $15-19$.

Островский, А. Н. Бесприданнищуа. Москва: ГИХЛ, 1950.

Хисамова, Г. Г. Языковая личность персонажа в художественном тексте. Вестник Челябинского государственного университета. 2014 (336/7), c. 214-217.

Чехов, А. П. Три сестры. Москва: Наука, 1986.

\section{Интернет-источники}

Режим доступа: http://portalkatowicki.pl/kultura/teatr/5321-zywiolowy-ozenek-wslaskim (2020-03-01).

Режим доступа: http://www.dziennikteatralny.pl/artykuly/opowiem-wam-gogola-poswojemu.html (2020-03-02).

Режим доступа: http://domagalasiekultury.pl/2015/11/03/nie-rade-kury-na-weseleozenek-nikolaja-kolady-w-teatrze-slaskim/ (2020-03-01).

Режим доступа: https://www.rp.pl/Teatr/151029239-Ozenek-czyli-wizja-Rosji.html (2020-03-03).

Режим доступа: http://rushist.com/index.php/literary-articles/2834-gogol-zhenitbaanaliz (2020-03-01).

Режим доступа: http://www.dziennikteatralny.pl/artykuly/opowiem-wam-gogola-poswojemu.html (2020-03-02). 